\title{
Experience versus Authority: The Search for Gender Equality in Chaucer's “The Wife of Bath's Prologue
}

\author{
Setefanus Suprayitno
}

\begin{abstract}
Over the past few years much interest has been put on gender equality. There has been a changing perception of the attitudes which emerges and shapes women's role in society and relationships. Formerly, social ideas and customs dictated women to be subservient. But now the changing social structure gives women space to pursue gender equality. Geoffrey Chaucer (ca. 1343-1400) had addressed this issue in his work, "The Wife of Bath's Prologue and Tale." This paper discusses how Alisoun, the wife Bath, through her prologue and tale, shows the contradiction of the oppressive traditions and customs imposed on women and attempts to present the idea of gender equality.
\end{abstract}

Keywords: Gender equality, The Wife of Bath's Prologue and Tale

Experience versus authority: the first three lines of "The Wife of Bath's Prologue" form the idea presented by Alisoun in her prologue and tale. Here she questions male authority. She uses her own concept of experience as her tool for questioning authority. In medieval times, the term authority was loaded with significance. That term carried the weight of the important thought of the past as recorded in books. Reading books, much less writing them, was the privilege of a small minority, usually the church and the aristocracy, both bastions of male power, where the prescribed ideals for women came from. It was the men who said what women should be or should not be. Eileen Power writes, "The ideas about women were formed on the one hand by the clergy order, usually celibate, and the other hand by a narrow caste, who could afford to regard its women as an ornamental asset, while strictly subordinating them to the interests of its primary asset, the land" (9). The culture's ideology about women's nature and behavior was formed, then, by two groups of powerful men who had little knowledge about the everyday lives of the majority of women. Such an authority is used for oppressing women and it puts women into a disadvantageous situation.

Alisoun raises her concern about this by citing Aesop's fable about the painting of a lion. The lion complains of a picture showing a man killing a lion, and says that it must have been painted by a man, because if a lion had painted it, the result would have been different. Just so, Alisoun says, if women told tales of marital woes to match those of the authorities represented in books, they would show men's wickedness more.

Who peyntede the leon, tel me who?

By God, if wommen hadde writen stories,

As clerkes han withinne hir oratories,

They wolde han writen of men moore wikkednesse

Than all the mark of Adam may redresse. (Lines 92-96) 
The fable Alisoun quotes expresses the relationship of "auctorite" and "experience," which she proclaims in the first line of her prologue. She does not deny authority when authority is true. However, she insists that authority should make itself accountable to the realities of experience. The fable of painting the lion teaches the "truth" that any picture has more to do with the prejudices and predilections of the painter than with the "reality" of the subject. Alisoun uses her experiences for justification since in her opinion, authority cannot be denied when it is true and accountable to the realities. As David Williams writes, that Alisoun is like an "aggrieved maiden seeking justice" (70).

\section{Experience versus Authority}

Alisoun opposes the concept of authority by using her concept of experience. Experience allows the individual to respond to questions discussed by the authority:

Experience, though noon auctoritee

Were in this world, is ynogh for me

To speke of wo that is in mariage. (lines 1-3)

Experience is personal and subjective. It does not require special training or access to formal education. What it does require is the living of a life. In Alisoun's context, authority equals men, whereas experience equals women. The opinions about women recorded in books are not true since the authorities who wrote them, being men, had no experience of women. So, in this case the authoriy is not accountable to the reality of the subject. Women, who naturally have experience of themselves, were not considered authorities, even on themselves. Here, through her speech Alisoun tries to show the distortions and omission in the mind of authority

Upon this nombre diffinicioun.

Men may devyne and glosen, up and down. (lines 25-26)

Men, in her opinion, love to interpret, distort, and imagine they know the truth (line 26). She thinks that the representations of women popular in church writing are inadequate and biased because they are interpreted based on male perspective. She knows that all the descriptions of women represent choices and patristic representations of women are drawn from selected passages within scripture, particularly those demeaning women, and maintaining the status and male power.

\section{Biased Church Writing about Women}

Public speaking before an audience as done by teachers and preachers, is a strong way to claim authority. The subject on which Alisoun claims authority through her experience is women's life. Therefore she questions the church's writing about women, which she considers as biased since those who wrote them, do not understand women. The representations of women in there are articulated by male voices and perspectives, they reflect more about men's views of women, rather than women's views of themselves.

It is very clear from her many references that Alisoun is familiar with the bible, the early church theologians, and a great variety of Greek and Latin classics. In other words, she is well-educated and knows all the great "auctors." Her mastery of "scole maters," as shown in her argument impresses others. The Friar says, 
'Dame,' quode he, 'God yeve yow right good lyf!

Ye han heer touched, also moot I thee,

In scole-matere greet difficultee. ("The Friar's Prologue," lines 6-8)

Nowadays it is very common that women have the same access to education as men do, but for a medieval woman to know all those things is a defiance of medieval idea of order. To use her knowledge to engage in theological disputation is an excedingly unladylike, even a subversive activity, "for it is a shame for women to speak in church" (I Cor 10: 34-35). That is the reason used for barring women from speaking. But Alisoun defies this idea when she questions the clerical criticism of virginity, marriage, and sex, by pointing out that without sex, there would be no virgins in the first place.

And certes, if ther were no seed ysowe,

Virginitee, thanne wherof sholde it growe? (71-72)

Though it is permitted, marriage is considered as inferior to perpetual virginity. If people wished to be perfect, they would join a celibate religious order. If they could not be perfect, if they found that a lifelong commitment to abstinence from sexual intercourse was too difficult, then marriage would be the second best choice. Alisoun, in this case, attacks the church's interpretation of the conception of marriage and virginity, posed by St. Jerome, who ranks marriage third after virginity and widowhood in its spiritual "yield" (64). He uses his interpretation of the text of I Corinthians 7 for defending his argument. St. Paul says, "It is not good for a man to touch a woman." (I Corinthians 7:1) And based on that scripture, St Jerome says,

If it is good not to touch a woman it is bad to touch one: for there is no opposite to goodness but badness. If however it is bad and the evil is pardoned, it is for this reason that allowance is made, namely to prevent a worse evil. But surely, a thing which is only allowed because there may be something worse has only a slight degree of goodness. He would never had added 'let each man has his own wife', unless he had previously used he words 'to avoid fornication'. (64)

By giving a privilege to virginity, Alisoun argues, church writing as such contradicts what the Bible says: "Be fruitful and multiply" (Genesis 1:28), and "Therefore a man leave his father and his mother, and shall cleave unto his wife: and they shall be one flesh" (Genesis 2:24). Alisoun says,

But wel I woot, express, withoute lye,

God bad us for to wexe and multiplye. (lines 27-28)

Alisoun also shows her candid argument when she handles the objection of remarriage based on an event in the Gospel (John 2:1-11) describing that Christ only visited one wedding feast. She asks where in the bible remarriage is explicitly forbidden.

Eek wel I woot, he seyde myn housbonde

Sholde lete fader and mooder, and take to me.

But of no nombre mencion made he,

Of bigamye, or of octogamye;

Why sholde men thanne speke of its vileynye? (lines 30-34)

She also questions whether the fact that Jesus attended one wedding feast in Cana really means that people can only marry once (lines 10-13, 17-18). In her opinion, those 
clerks create misreading of the bible. She also tackles the story of a Samaritan woman (John 4:5-19) which is commonly interpreted by church authorities as a prohibition against remarriage. She says that Christ Himself does not specify how many times it is lawful to marry. She also cites that the wise King Solomon, who had seven hundred wives and three hundred concubines, to support her case for multiple marriage. In other words, Alisoun calls into question the accepted church teaching on the story and decides to interpret it for herself. In doing so, she defies ecclesiastical authority and use her own "authority" instead, like what Alan of Lille says, "Authority has a waxen nose; that is, it can be turned in either directions" ("Auctoritas cereum habet nasum: id est, in diversum potest flecti sensum") (Mann 72).

No matter what the church might say, Alisoun sets her own experience against it. If the church gives privilege to virginity, she says that she is not interested in being a perfect Christian. Instead, she prefers to be an adequate one. She supports her stand by citing the theological distinction between a counsel and a commandment. A commandment is an order to avoid sin, for example, "Though shall not commit adultery." Such an order binds everyone in all circumstances. A counsel is, on the other hand, a suggestion, a piece of advice on how to increase in virtue, like taking a vow of perpetual virginity. So Alisoun says, "counselling is no commandment." (line 73) It is not wrong to choose the less virtuous path.

Alisoun illustrates the difference between a counsel and commandment about virginity by a metaphor. She uses to two everyday household objects: dishes and bread. She says, that

For wel ye knowe, a lord in his houshold,

He nath nat every vessel al of gold. (lines 99-100)

Virgin are like the gold vessels in God's household, like the good dishes in a modern household saved for special occasions: precious but untouched. Wives are like the inexpensive everyday plats made of wood in the Middle Ages: of less value but used everyday.

Similarly, virgins are like "pure wheat-seed", the flour from which white bread was made. White bread was considered a delicacy in the Middle Ages, suitable for an aristocrat's table; peasant would eat dark bread. Wives are not so special as white bread; they are ordinary like "barley-bread" (line 144). Everyone has his or her own "proper gift" (lines 103) or role to play, even if it is imperfect and inferior one. Because she is not interested in being perfect, she need not obey all the recommendations set for those who would be.

Alisoun also talks about sexuality in her argument about the authority. Her explicit sexuality is the trait for which she is most often remembered. Her belief and behavior are in flagrant opposition to what medieval people saw as appropriate sexual expression within marriage. She sees marriage as basically about the use of what she calls the "member... of generation" (lines 116), the sex organ. She asks why God would have made people with male and female sex organs if He did not intend them to use these organs. She asserts that sex organs are not merely for purgation of urine or for distinguishing a female from a male; they are also designed to pay what medieval people thought of as the marital debt. This concept in medieval canon law (church regulations) obliges husbands and wives to have sex with each other on demand. On the other hand, medieval canon law also restricted the number of times a married couple might have intercourse, so that they would not be excessive in their demand on each other. But in Alisoun's way of thinking, she intends to use her "instrument," sexual organ, as generously as God gave it to her. 
In wyhod I wol use myn instrument

As frely as my Makere hath it sent. (lines 149-150)

If she is coy, or plays hard to get, she asks that god punish here as if for a sin. Her husband can pay his marital debt, anytime he wants to; but she will also require him to have sex whenever she wants to. She reasons that she deserves the right to make these demands, and by medieval standards, she does. But to exercise marital rights in this frame of mind is morally wrong, even, in marriage because it is excessive, selfish, and unloving.

\section{Gender Equality}

From what she tells her audience in her prologue, Alisoun shows that women do not have the right even on their own lives. What women should do is what male authority has prescribed, which has the dominant position over women. Judith Bennet, in her study, Women in the Medieval English Countryside, found that women's subordinate position in fourteenth-century culture was the same kind of subordination, regardless of class. It was a subordination maintained by excluding women from public sphere, the only sphere that granted social power (44). If women were instructed to accept the inferior status in the church and in public world, they were also instructed to accept an obsequious role at home. "Ideally," and by in large, fathers, husbands, brothers, and other male relatives shaped and controlled women's domestic lives.

Because of the conditions repressing women and making them the subordinates of men, Alisoun tries to show that gender equality is more important than the authority that is often misused. If men were in the position of women, they would know how unfair the "authority" was. She uses the story of a rapist-knight to voice her idea about gender equality. By medieval standards, rape is a very serious crime since the victim has been robbed of an irreplaceable treasure: her virginity. And in the kingdom of King Arthur, rape is a capital offense, and the rapist-knight is condemned to death. Before carrying out the death penalty, King Arthur at the request of the queen and her ladies, gave clemency to the knight on one condition: the night should undergo a journey to learn "what things it is women most desire." In her wisdom, the queen does not intend to provide dispensation for the rapist without the assurance that he is truly converted, thereby, endeavoring to make sure he will not go out and rape again.

In his journey, the rapist-knight encounters his counselor, the loathly lady, whose treatment includes making the assailant fully aware of the role of victim when he himself is placed in a situation of victimization and making him listen to sermon on gentilesse.

When confronted with his impending marriage to the loathly lady, the knight utters a plea that we can imagine has crossed the lips of a woman facing an attacker, "Taak al my good and lat my body go" (lines 1061). Here the knight's true lesson, brought about through experiencing what gender inequality has done to women, begins. Having been reduced to a piece of property, he attempts to barter other possessions so that his most precious one, his personhood, might not be victimized. He comes to understand what it feels like to be forced into a marriage that is not of his choosing. His protest against what he views as his "dampnacioun" (1067) are not listened to. He is stripped of his power and his will. To him, his wedding night will be a rape. Thus the 
loathly lady reveals to the knight what it is like to be marginalized and to be stripped of self-governance.

When the newlyweds are alone, the loathly lady lectures the knight about socially constructed value. As an ugly, old woman, the loathly lady is a contradiction to most of the cultural values with which the knight has been infused. That an older women expresses her sexual desires conflicts with both the notions that women should be passive and the notion that an old women, one who is beyond her child-bearing function, desires pleasure from sex is "a moral evil."

In order to find out if her disciple has truly listened to her words, at the end of the lecture, the lady offers him a difficult choice: she can remain in her old and ugly form yet be a faithful wife to him, or she can transform herself into a beautiful, young bride who may be unfaithful. The old woman's offer is indeed a test of the knight's progress, because it involves two traits that the system of male dominance values in women: beauty and fidelity. According to the loathly lady's options, however, the knight cannot have both qualities in his bride. The line "This knyght avyseth him and sore siketh" (1228) realistically indicates the struggle the knight has in renouncing the gender role with which he has been indoctrinated since his childhood. Yet he surrenders in this struggle, as is indicated by his following speech.

But atte laste he seyde in this manere:

"My lady and my love, and myf so deere,

I put me in youre wise governance;

Cheseth youreself which may be moost pleasance

And moost honour to yow and me also.

I do no fors the wheither of the two,

Fpr as yow liketh, it sufficethe me." (lines 1229-1235).

Here the knight relinquishes his need for absolute control, and places his fate in the hand of another person. In choosing an alternative solution to this test, the knight proves that he has learned the lesson of individual will. He has realized that it is not for him to impose any personal preference in determining something so private as how a woman should appear and, subsequently, recognizes the flaws in a system of gender inequality. Having thus received the proof that the knight has learned his lesson, the loathly lady transform herself into a young, beautiful woman who will also be faithful to her spouse. The transformed couple in their nuptial bed represent a world in which individual share mutual respect and equality.

\section{Conclusion}

Through her prologue and tale, Alisoun takes a stance which is uncommon for a medieval woman. She asserts that male authority puts women in a disadvantageous positions. Women do not have the authority even over her own life since every aspect of their life is prescribed by those who do not know about them. Alisoun's prologue voices how the male authority uses church writings, interprets and misinterpret them to justify their action. And in countering it, Alisoun also approaches theology, both the scripture and the writings, and interprets and misinterprets them to justify her arguments.

Reading what Alisoun illustrates in her Prologue and Tale, we may understand why she tries to interpret and misinterpret all the church writings, and even to quote 
them without considering their context, for supporting her argument. Her experience proves that men subordinate women, and they use their own interpretation of church writing in such a way that they can find support in them. They misinterpret it based on their own benefit. Through her tale, Alisoun says that there is more to being a decent human being, whether male of female, than what the prescribed definition of patriarchal power system dictates. She suggests that people should work to dispel the prescribed gender notions, which are often used to "abuse" women. Gender equality is the key to human fulfillment, as it is shown at the end of the story that after adhering gender equality, the husband and wife live happily ever after.

\section{References}

Bennet, Judith. (1987). Women in the Medieval English countryside. Oxford: Oxford University Press.

Chaucer, Geoffrey. (1992). The wife of bath's prologue and tale. In Canterbury tales. A. C. Cawley, (Ed) London: David Campbell Publishers Ltd.

Crane, Susan. (1994). Gender and romance in Chaucer's Canterbury tales. Princeton: Princeton University Press.

The holy bible. (1985). The Gideon International. ed.

St. Jerome. Against Jovinian. In Alcuin Bramires, Karen Pratt, and C. W. Mark (Eds.). Women defamed and women defended: An anthology of medieval texts. Oxford: Oxford University Press.

Mann, Jill. (1991). Geoffrey Chaucer. Hertfordshire: Harvester wheetsheef,

Power, Eileen. (1975). In M. M. Rostan (Ed.) Medieval women. Cambridge: Cambridge University Press.

Rigby, S. H. (1996). Chaucer in context: Society, allegory, and gender. Manchester: Manchester University Press.

Williams, David. (1987). The Canterbury Tales: A literary pilgrimage. Boston, Twayne Publishers. 